\title{
MEMOIR WARREN O. NELSON \\ 1906-1964
}

Warren O. Nelson was born in Moline, Illinois on 16th April 1906. He received a Bachelor of Arts degree from Augustana College in 1928, a Master of Science degree from the University of Iowa in 1929, the degree of Doctor of Philosophy from New York University in 1931 and an honorary degree of Doctor of Medicine from Justus Liebig Universität, Giessen, Germany, in 1957. He was associated as a teacher and investigator with the University of Chicago, the University of Missouri, Yale University, Wayne University and, in 1956, returned to his alma mater, the University of Iowa, as Professor of Anatomy.

Doctor Nelson became the Medical Director of the Population Council, an organization devoted to the study of human fertility problems, in 1954 . In July of 1964, he joined the staff of the Albany Medical College of Union University as the Associate Director of the Institute of Experimental Pathology and Toxicology, as Professor of Anatomy and of Endocrinology. His death occurred on 19th October 1964.

Doctor Nelson had written about 200 scientific papers in the fields of reproduction and endocrinology. He was a past-President of the Endocrine Society and was affiliated with many other scientific organizations, including honorary memberships in numerous societies outside of the United States. $\mathrm{He}$ served on the Medical Committee of the Planned Parenthood Association, as well as on several other national and international committees.

Doctor Nelson was the recipient of several awards including the Albert and Mary Lasker Foundation Award in Planned Parenthood in 1956. This award cited him as having "labored long and well for the advancement through science of man's knowledge of his problems and their solutions". The award further stated that, "his studies of the biology of spermatogenesis have made a fundamental contribution to the field of human reproduction. He has toured the world as a veritable ambassador of science, inspired, advised and guided investigators all over the globe on the problems of reproductive physiology allied to population control."

This, we believe, is as fine a chronicle of Warren Nelson as can be written.

Albany Medical College,

Frederick Coulston

New York

J. M. WOLFE

1965 
The Editor is grateful to Dr Robert Gaunt for permission to reprint the address he delivered at the Memorial Service held in Rensselaer, New York, on 21st October 1964.

On this occasion I cannot but speak in personal terms. I knew him well enough to know that nothing would be more distasteful to him than public sentimentality on this occasion. Nevertheless, disdainful as he may have been of sentimentality, sentiment he himself felt-deep, moving, loyal and true-and of such were the foundations for his uniquely strong character.

Those of us who knew him well and enjoyed his friendship would be less than true if we failed to express, inadequate though our means may be, our deep-felt sentiments today.

Warren Nelson was born on April, 16th 1906, in Moline, Illinois. His early years were spent in Texas and Oklahoma. After his father's death he went to high school in Wisconsin. In his later years, as he traveled widely, and was known and welcomed in all world capitals, he still bore proudly the stamp, the character, and the accent of the plains and frontier of this nation-a frontier that furnished many men to our academic life and the science of Endocrinology in particular.

Concerning him it might be said, as was recently said of another, "The hill country of Texas is a stern adversary, giving grudgingly of itself only to the most determined.... Here at the grass roots of America, where the soil is meager and the sun is hot, he learned about life and about people."

Being born with no silver spoon in his mouth, he compensated by relentless hard work. Except for rare intervals, this work never ceased. It was his great good fortune, and essential to his own happiness, that he was able to continue working until the last moments of his life.

For the short periods, however, in which work was put aside, this too was thoroughly done. Sports of any kind provided strong competition for the urge to work and he leaves us all fond memories of gay and relaxed evenings at many times and places.

His higher academic work started at Augustana College, Rock Island, Illinois, in 1924. There he came under the influence of one of those great small-college teachers, Professor Harold Yingling, who directed his interests toward the biological sciences.

He emerged with a degree in 1928 and soon then was engulfed in the great depression, during which for him, as for his contemporaries, the going was hard.

But on small resources he started graduate work at the University of Iowa where W. W. Swingle was rejuvenating a department. When that group broke up, he moved to New York University with the late Hans Haterius and with Harry Charipper. There he received his Ph.D.

From there he went to the University of Chicago for postgraduate work with Carl Moore. Then came his first staff appointment at the University of Missouri with Milton Overholser, and the next one at Yale under Edgar Allen. This list of teachers is itself something of a galaxy of world Endocrinology-but in every institution in which he learned, he contributed as well-a steady stream 


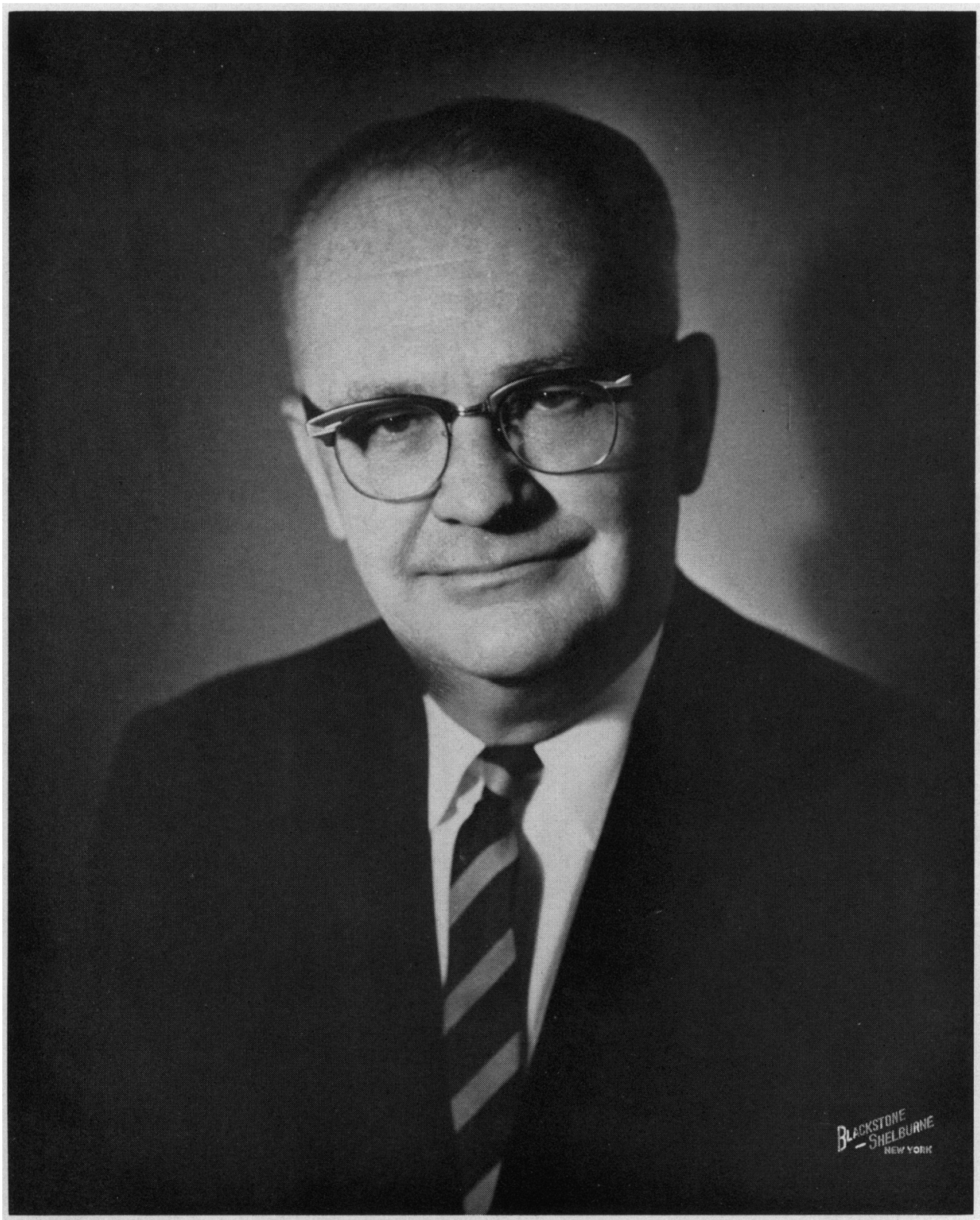

Warreno. Nelson, $1906 \quad 1964$ 
of basic sound research. This led to a Professorship at Wayne University and later, full cycle turned, back to Iowa.

Perhaps his greatest institutional achievement, accomplished at a time when the need was great, was the magnificent world-wide medical program he set up for the study of population problems under the auspices of the Population Council. This blooms now as a great and forceful world effort at a time of emergency.

The shock felt by all of us today is particularly acute among the many students and protégés, American and foreign, who at one time or another worked with him. For them he found plenty of time at any cost and through them his techniques, philosophies and high standards write broadly the record of their beginnings.

The work of such a man is never done, but the main unfinished job was the one he left here-for he certainly had a great role to play in the development of the new Institute with which he was briefly associated in Albany.

I will not dwell on the many honors, honorary offices, honorary degrees, and so forth which he held-through which world-wide science proclaimed its respect for him and his accomplishments. This is the material for formal biographies and these will be written. As was said of Christopher Wren, we can say, "If you would see his monument, look around". His were not made of stone but they are immortalized in our institutions and in what is becoming the common knowledge at the foundations of scientific development.

But it is on his capacity for friendship that I would prefer to dwell today, and frankly with deep sentiment. I do not know if he ever read these words of Emerson, but he practiced them: "The highest compact we can make with our fellow man is,- Let there be truth between us two forevermore."

I knew him first when he was a graduate student at New York University and $I$ at Princeton. A short time later our long collaboration began, which in one form or another, with some intermissions, continued until now. From him I learned much, but what I appreciated most was the utterly honest and dependable help, whether with personal or professional problems, on which I knew without doubt I could depend.

I called for this help often and feel a great void that I cannot do so again. I am sure many others of you here know and share that feeling. It is being expressed by many people in many nations. Because with him friendship was not just a commitment but a dedication-a dedication not to be entered upon lightly or turned from casually. It could be enjoyed, as it was by me, in the old Greene Street laboratories off Washington Square in our youth, on the hot streets of New York on summer nights with our wives, at the Cold Spring Harbor laboratories and beaches, and perhaps most of all during every year but one since 1937, on far-flung golf links from coast to coast, where, as in all other of his undertakings, he was a formidable competitor.

In July 1931, Warren Nelson married Caroline Louise Kramer-known much more generally as Patty. To Patty and Warren, Jeannine was born and now there is a son-in-law, James Graham, and two grandsons, David and Kevin Graham. Together they were a devoted group and the center of his affections. 
To them our deepest sympathy. But with them we can say of their husband, father, grandfather:

Here was a man among men. We salute him today.

Ciba Pharmaceutical Products Inc.,

R. Gaunt

Summit,

New Jersey 